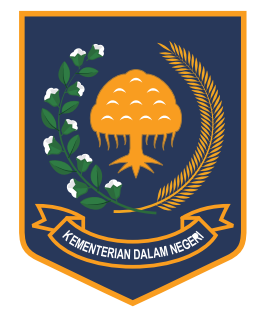

Jurnal Bina Praja 10 (1) (2018): 57-67

Jurnal Bina Praja

e-ISSN: 2503-3360 | p-ISSN: 2085-4323

Accreditation Number

735/AU2/P2MI-LIPI/04/2016

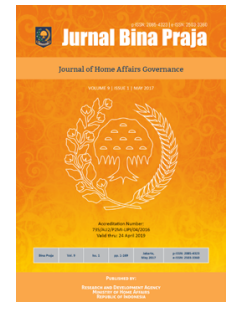

http://jurnal.kemendagri.go.id/index.php/jbp/index

\title{
Fiscal Condition of Sumatra in Decentralization ERA
}

\author{
Joko Tri Haryanto* \\ Center for Climate Change Financing and Multilateral Policy, Fiscal Policy Agency \\ Ministry of Finance of the Republic of Indonesia \\ R. M. Notohamiprodjo Bld., 5th Flr, Dr. Wahidin No. 1, Jakarta, 10710, Indonesia
}

Received: 3 January 2018; Accepted: 23 March 2018; Published online: 12 May 2018

DOI: $10.21787 / j b p .10 .2018 .57-67$

\begin{abstract}
Indonesia has been running a decentralized reform era since 1 January 2001 . The goal of decentralization is to accelerate the realization of prosperity through the improvement of public services. Fiscal decentralization then became the main benchmark of the successful creation of indicators of regional autonomy in addressing various problems in the regions, especially inequality and poverty. According to government data, Sumatra recorded a major contributor to national GDP growth while facing poverty, inequality constraints and also the largest mining sector. By using the shared and growth analysis and quadrant method, this research tries to provide policy-making recommendations based on the characteristics of the regions in Sumatra. Based on shared analysis, the biggest region is Bengkalis Regency, Riau Province, Siak Regency, Rokan Hilir Regency, and Musi Banyuasin Regency. For the smallest region, it consists of West Nias Regency, North Nias, Toba Samosir, Gunung Sitoli and South Nias. From the growth analysis, it was found that Mesuji Regency, Southeast Aceh Padang Lawas Utara, Kota Padang Panjang and West Nias Regency have the highest growth in Indonesia. From the quadrant method, 20 regions are in quadrant I, about 54 other areas are in quadrant II, and 35 areas are in quadrant III. The largest part of the regional classification in the region of Sumatra is in quadrant IV. Based on these findings, fiscal policy in the future should be prioritized to develop on regional eradication in quadrant IV in terms of Transfer to Region.
\end{abstract}

Keywords: Share Analysis, Growth Analysis, Quadrant Method, Local Independence, Fiscal Decentralization

\section{INTRODUCTION}

The implementation of reformation era's decentralization started since 1 January 2001 is the answer to the failure of centralized planning system toward the regional development and economic planning program, besides the awareness arising from the central government on the importance of the regional government role (Cahyono, 2014). This decentralization relationship pattern has been carried out in the hope of cutting the bureaucratic chain through the delegation of authority from central government (Samora, 2010).

This is similar to the public policy theory implemented in many countries. UNDP (United Nations Development Programme) (2009) stated that the essential purpose of the implementation of decentralization in a country is to accelerate the realization of public welfare through improvement of public services.
Decentralization also becomes a mechanism in order to return the dignity of a local community, to give political education to improve the democratic quality, to accelerate development as well as good governance and transparency (Habibi, 2015).

The advent of motivation to implement the decentralization process especially in the developed countries are influenced by many factors. The research of Kharisma (2013) mentioned that the greatest factor is the country circumstance or experience, its role in the world of globalization, recession of economic development, demand of changes in the level of public service, signal of disintegration of nation, as well as the failure of government with centralistic characteristic in delivering effective public services.

Owing to this, the implementation of fiscal decentralization is assigned to these three aspects, namely political decentralization, administrative

\footnotetext{
* Corresponding Author

Phone : +62817 6069905

Email : djohar78@gmail.com
} 
decentralization, and fiscal decentralization. The fiscal decentralization then becomes the main benchmark for the successful implementation of decentralized relationship patterns, through indicators of regional independence.

The indicator of regional independence is analyzed from fiscal revenue through enhancement of regional capability in exploring Local Own Revenue (PAD) (Indriyani \& Pandansari, 2016). Fiscal decentralization is also regarded as the essence of decentralization implementation to carry out the authority, responsibility, and duties of public services without being authorized in terms of both income and expenditure aspects (Supriyadi, Armandelis, \& Rahmadi, 2013).

Therefore, along with the delegation of authority into the region, the sources of revenue shall be handed over too, in accordance to the money follow function philosophy, by also considering the awareness that the sources of revenue between regions quite vary. For this reason, creativity and initiative are in needs to explore their own potential (Basri, Syaparudin, \& Junaidi, 2013).

In other hands, the characteristic of regions in Indonesia varies greatly. Some regions are gifted with the abundant natural resources, while other regions have abundant tax revenues. However, most of the remaining regions do not have sufficient source of funding. Therefore, the central government introduced fiscal transfer policy to Region (TkD) which consist of components of Revenue Sharing Funds (DBH), General Allocation Funds (DAU) and Special Allocation Funds (DAK).

The DAU component is a block grant policy aimed at reducing regional inequalities, while DAK is a policy specific to accelerated development. To reduce the gap between central and regions the government allocated the DBH (Sasana, 2011).

Through the implementation of the fiscal decentralization, the regional government is stipulated to taking the role to manage their own financial aspect independently, therefore the whole potential shall be optimized through effective and efficient regional development and budgeting mechanisms (Saputra, 2014).

They are also required to be more transparent in their local financial management by upholding the public accountability aspect. Therefore, it is necessary to have a regional financial management system based on the concept of value for money and oriented to performance through the assessment of credible regional financial reports (Tama, 2015).

Ultimately, the overall aspect between increasing PAD capacity, regional independence, regional financial management systems, public accountability, and value for money will lead to improved regional status in global competition (Wenny, 2012).
Several research results are able to explain these expectations. Research of Pujiati (2008) enchanting the theme of the impact of decentralization and economic growth in the Residency of Semarang, which concluded that the increase in PAD brings a positive impact for the increase of economic growth.

Another salient point stated by Nurhemi \& Suryani (2015) which explains that regional financial autonomy in the nation has a positive and significant effect on economic growth in the period of post fiscal decentralization. Hence, regional independence could boost the economy of the respective province.

Another reinforcement was also carried out by Apriesa \& Miyasto (2013) which calculated the effect of fiscal decentralization on regional economic growth and income inequality across districts in Central Java. With the increasing independence in the era of fiscal decentralization, regional economic growth shall grow and generate a great demand for labor absorption.

The similar things are mentioned by Taqwa, Priyono, \& Santosa (2016) with research locus in East Java Province. It specifically mentioned that fiscal decentralization encourages economic growth in East Java province, especially in the central business or industrial area.

Different dimensions are presented by Allo \& Mahi (2014) which explains the relationship between the fiscal independence aspect and the efficiency of spending in Central Java. Level of independence of region, in fact, is positively correlated with regional government spending efficiency level. In which region with high PAD proportions will have better spending efficiency.

This finding is also in line with modern decentralization theory where the efficiency of local expenditure can be enhanced by the implementation of fiscal decentralization. Sasana (2009) also found a significant relationship between the implementation of fiscal decentralization in Central Java province with the increasing economic growth, declining inequality among regions and reduction of unemployment in the regions.

Sasana (2015) also conducted at provincial level throughout Indonesia by adding an indicator of inflation. The conclusion is alike to the previous research, in which fiscal decentralization has a positive impact on economic growth and employment. In regard to the inflation indicator, it is concluded that there is a positive relationship with fiscal decentralization, but it has not been proven significantly.

Despite a relatively large number of studies outlining the positive impacts of fiscal decentralization, several other studies still manage to come to an agreement that fiscal decentralization has a negative impact on the region. In general, the 
entire study finds indications of regional government dependency in the era of fiscal decentralization on central government assistance, especially through TkD mechanisms.

Sagala \& Parmadi (2013), for example, in the case of regional financial capacity in Jambi and Batanghari districts, which finally found evidence of low fiscal decentralization ratios in both regions. The research was done by A. (2013) with the theme of fiscal decentralization and economic growth cope with its relationship with regional autonomy, also concludes that in the era of fiscal decentralization and regional autonomy, local government spending is mandatory to be reorganized to reduce the dominance of administrative personnel spending.

Sianturi, Sjamsuddin, \& Domai (2014) also analyzed the role of PAD in supporting fiscal decentralization and regional development in Batu City. By using the fiscal decentralization degree ratio, it can be concluded that PAD played an insignificant role in improving regional autonomy in Batu City in the era of fiscal decentralization. This is proven by the degree of fiscal decentralization in Batu City that is still smaller than $10 \%$.

The research by Yuana (2014) conceivably is the relatively most comprehensive than any other research. It is mentioned that the ratio of independence and effectiveness of the region has a direct positive effect directly on economic growth and both contribute respectively about $25 \%$ and $19 \%$ to economic growth in East Java Province.

Referring to the same material, the government plans to use inclusive growth strategy mechanisms to address regional inequality and poverty. The Finance Minister correspondingly pointed out that horizontal inequality still occurs where the sources of national economic growth are still dependent on the West Indonesia Region (KIB), especially Java, which contributes $58.5 \%$ of national GDP and Sumatra about $22.0 \%$ of national GDP.

Nonetheless, the Java itself still faces a poverty rate of $10.1 \%$ while Sumatra has $11.1 \%$. Thus, the mapping of economic potential and regional autonomy in Java and Sumatra becomes very interesting to be analyzed. Since the analysis in Java has been completed earlier, this study will focus on the analysis in Sumatra.

This research incorporates certain issues as problem constraints. Firstly, related to the matter of the substance analyzed which only includes the element of revenue and expenditure of APBD without the quality and mechanism aspects of the policies related to the income and expenditure itself. Secondly, related to the APBD data that analyzed exclusively using 2010-2016 data basis, whilst the 2010-2015 data is the data of APBD realization being sent to the central government. Meanwhile, 2016 is budget data.
Theoretically, Oates $(1972,2011)$ presenting many principals which could be used to explain the relationship between fiscal decentralization and economic growth. He stated that economic efficiency basically can be elevated through delegation in form of fiscal decentralization towards lowest hierarchy government, therefore, causing the increment of economic growth either in the national or regional basis, same understanding also conveyed by Tiebout (1956).

These theories can explain the existence of democratic mechanisms in the implementation of fiscal decentralization in the region, although it is opposed by Rondinelli. Rondinelli (1989) stated that decentralization and democracy are different concepts, neither mutually exclusive nor related as well. Within a centralized government, there can also be a democratic mechanism when officials are regularly elected by the people.

However, Litvack, Ahmad \& Bird (1998) actually equates decentralization to democracy in its implementation. Democracy provides support for decentralization and decentralization provides increasing participation in democratic life in the region. The aforementioned decentralization in the context of the democratization process in the regions needs to be understood as a public decisionmaking instrument that has broad implications for social, political and economic aspects.

Hence, decentralization should be translated into political, administrative, fiscal and economic decentralization (Tiyaningsih, 2009). Decentralization then becomes a necessity for Indonesia in producing the local government that has a political variety to channel local voice and local choice. Decentralization is intended as an instrument capable of accommodating the aspirations of a pluralistic society with diverse conditions and potentials (Magno, Hakim, \& Domai, 2015).

Hans Antlov as quoted by Suharizal (2012) asserted that in the state of unity either centralized or decentralized, the regions, organs or institutions gave autonomous right is being granted by the central government. The granting of such autonomous rights may be withdrawn either in the authority or in regional legislation rights without having to seek prior approval from the regions.

The government authority itself becomes the basis for any doing or law action from every governmental level prevailing in Indonesia. By the existence of the legal basic authority, thus any doing or law action from every governmental level can be categorized as an illegal behavior in which against the law or violation against the general principles of credible government (Muin, 2014).

The separation of authority in its implementation is also accompanied by the 
separation of financial affairs between the central and regional governments as the core of the implementation of fiscal decentralization. Such separation may include separation from the revenue and expenditure side with the main objective of empowering the region in achieving independence (Enceng, Irianto, \& W., 2012).

In the opinion of Halim (2001) in Sumarsono (2009), the main feature of a region that considered capable of exercising its authority is their ability and authority to explore the potential of its own sources of financing. Therefore, the APBD in the future should reflect a rational spending strategy from both qualitative and quantitative aspects.

In the end, a tight-knit relationship exists between the usage of the facility and its income, as well as the pattern of government spending that can be taken into consideration in determining the acceptance pattern which at the end assures the level of income distribution and allocation of local economic resources under optimal conditions (Anwar, Kumenaung, \& Kawung, 2015).

In Law No. 23 of 2014 regarding Regional Government, APBD is an annual financial plan of the Regional Government and also considered an annual financial plan of the region that describes the budget to finance local activities and projects within a budget year and on the other hand, describes the local revenue to finance budgeted expenditures.

Therefore, the APBD is then become the reflection of the performance and ability of local governments in financing and managing the implementation of governance and implementation of development in their respective regions in one budget year as well as a product of budget politics in the region (Efendi \& Wuryanti, 2011).

To support the creation of APBDs, the government has required the preparation of performance-based budgeting to all regions. Performance-based budgeting is a budget that emphasizes on work performance or outcomes. Unlike the conventional budgeting system, that focuses more on cost calculations (Nanda \& Darwanis, 2016).

This conventional budget system is dominant with budget-line-item budgeting scheme where the budgeting process is based on the realization of the previous year's budget so as to imply a business as usual (BAU) process without noticeable significant changes over the previous year's budget (Rampengan, Nangoi, \& Manossoh, 2016).

Sulistio (2010) added that this performancebased budgeting system will be directly linked to the outputs and outcomes to be achieved, with an emphasis on the effectiveness and efficiency of allocated budgets. Performance-based budgets are vital and have become a supporting effort for improving people's living standards, improving development effectiveness through better financial management and governance (Widyantoro, 2009).

As an objective, regional autonomy according to Mardiasmo (2009) has several benefits including 1) encouraging increased participation of community initiatives and creativity in development and promoting equitable distribution of development outcomes by utilizing available resources and potentials in the regions; 2 ) improving the allocation of productive resources through shifting public decision-making to lower levels of government, however having more detailed information.

The higher the independence of a region will have implications for the ability to exercise authority and public services. Thus, prime public service solutions are not always the only government domain (Harteti, Darwanis, \& Abdullah, 2014). The community also has a role in supporting the creation of independence in a region. So that this society can be the subject as well as the object of the creation of independence in a region (Apriana \& Suryanto, 2010).

In particular, the community who works as the State Civil Apparatus (ASN), also plays an important role in determining the quality of budgeting in local budgets. If the officials in this area are open and aware of the importance of local financial management, then regional independence is not impossible to be realized (Fatoni \& Nurhayati, 2013).

Central and regional government readiness is also the keynote of successful implementation of fiscal decentralization. The reversed understanding phenomenon shall not happen in interpreting the objectives of fiscal decentralization (Dwirandra, 2013). Susilo \& Adi (2007) has undergone the mapping of the weaknesses of fiscal decentralization infrastructure. The most urgent is the allocation of non-urgent public facilities development, inappropriate technical specifications and/or its low utilization that inflict low relevance to economic growth in the region.

\section{METhoD}

Looking at the method, this research is categorized as descriptive research, which is a research that collects the data and answer the research question regarding the latest status of a research subject. In this matter, APBD data is used to answer the economic potential mapping challenge and regions independency analysis of the Sumatera regions in the fiscal decentralization era. How can budget data explain economic potential mapping and regional independence?

From a research approach, this study purely uses a quantitative research approach presented through the calculation of ratios and indicators of share and growth to see economic potential and 
self-reliance analysis. Furthermore, the quadrant method analysis is used as a form of mapping the position of each region.

This study has not combined the findings with a qualitative approach to test the depth and quality and the resulting indicators may be distinguished in the ceteris paribus series or used as exogenous variables that are not analyzed. The type of data used in this study is entirely secondary data in the form of all APBD throughout Sumatra in 2010-2016. For 2010-2015 APBD data is using realization data while APBD year 2016 still use budget data.

The selection of 2010-2016 besides based on the constraint of data limitations is also caused by the contemporary factor of data in order to answer the problems that become the full responsibility of the government. The data obtained entirely from the official sources of the Ministry of Finance, c.q. Directorate General of Fiscal Balance (DJPK).

The method of analysis used is the quadrant method with a combination of indicators of share and growth that have been obtained in advance. The share indicator aims to analyze the region's independence in financing its APBD, while the growth indicator aims to illustrate the potential for economic growth in recent years. Mathematically, the formulation of the shared indicator can be explained as follows (Direktorat Pengembangan Otonomi Daerah-Bappenas, 2003):

$$
\text { Share }=\frac{(P A D+D B H)}{T B} \times 100 \%
$$

where:

$P A D \quad:$ Locally-Generated Revenue;

$D B H \quad$ :Revenue Sharing;

TB : Total Expenditure;

Meanwhile, growth ratio indicator using:

$$
\text { Growth }=\frac{(P A D+D B H) t-(P A D+D B H) t-1}{(P A D+D B H) t-1} \times 100 \%
$$

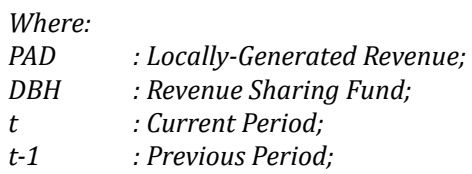

The use of quadrant method analysis will then divide the area into four quadrants with the explanation of each quadrant as follows (Direktorat Pengembangan Otonomi Daerah-Bappenas, 2003):

1. Quadrant I: is the ideal quadrant representation, as a result of a combination of regions with high share and growth characteristics;
2. Quadrant II: is a representation of the quadrant of the region that has not been optimal because of the regional revenue unable to play an important role in financing the APBD;

3. Quadrant III: also describes the condition of the region that has not been ideal in the opposite relationship with the previous quadrant. The area that is in quadrant III has the main characteristic of its big share but its small growth;

4. Quadrant IV: is a representation of the least ideal region because the role of local revenue is still small, and its growth is negative. Thus, the IV quadrant is characterized as a region with low share and growth.

As the research locus materials, selected regions in all districts/cities/provinces in the region of Sumatra. The selection of research locus in Sumatera was based on the contribution of Sumatra Island to the growth of national GDP (second largest after Java) as well as the regions in Sumatera which mostly rely on agriculture, processing and mining industry.

It would be interesting if the mapping of economic potential and independence could be used as a reference for future regional development based on the analysis of each sectoral strength. Based on which regions are the granaries of agriculture, regions that have the power in the processing industry and or regions that contribute to the largest mining sector.

\section{RESULTS AND DISCUSSION}

Based on the results of the calculations, the analysis will be presented thoroughly based on the discussion of each share, growth, and quadrant, with the explanation as follows:

\section{A. Share Analysis}

Based on the calculation results, the five largest regions, it uncovers the Bengkalis District with an average share of the year 2010-2016 amounted to 94.28 . Followed by Riau Province (88.96), Siak Regency (78.53), Rokan Hilir Regency (74.16) and Musi Banyuasin Regency (68.53). This position is unique because it is very different from the results of share analysis in Java which are still dominated by the province related to the provincial tax collection authority. Please detail a little bit this statement especially why tax collection authority becomes matter.

Meanwhile, for the case of Sumatra, the region with the largest share value is dominated by mining areas that have high revenue allocation of oil and gas (DBH). From the sectoral side, these regions are still 
highly dependent on the extractive industries. This condition is beneficial to the central government on the one hand because the burden of TkD allocation, especially from DAU, is reduced.

For example, Bengkalis Regency has 94.28 share which can be interpreted that the independence of Bengkalis Regency in exercising its authority is about $94 \%$ while the role of central government assistance only fills the deficiency of the remaining $6 \%$ and the five largest four regions came from the district and leaving only Riau as a Province. It is decent to say that the objectives of fiscal decentralization can be achieved.

On the other hand, for the regions themselves, it actually withdraws its own challenges, especially related to the phenomenon of a natural resource curse. The curse of natural resources is a phenomenon that occurs in a country or region that is rich in natural resources, but the wealth of its natural resources does not have a positive impact on society (Borge, Parmer, \& Torvik, 2015).

Research of Rosser (2006), Polterovich, Popov \& Tonis (2010) and A. (2016) describe in detail the occurrence of natural resource curses in some developing countries that occur due to some basic infrastructure weaknesses, such as weak human resource quality failure of non-mining sector development and other moral hazard of government officials and institutions.

Several types of research that captivating local cases in Indonesia have also been numerous and lead to the conclusion of many negative impacts that have been ill-managed by the resource-rich regions related to environmental aspects in the era of fiscal decentralization (Lounela, 2015) and (Irawan \& Tacconi, 2016).

Therefore, it is important for the five regions with the largest share to undergo the "Sectoral Migration" (transformation or migration) immediately using the initial modality of large oil and gas revenues. Non-mining priority sectors must be found, which have sustainable and reliable characteristics across generations of sectors, which are services, tourism, and other secondary industries.

For the list of regions with the smallest share, if grouped to the top five consists of West Nias Regency (5.72), North Nias Regency (6.18), Toba Samosir Regency (6.43), Gunung Sitoli City (6.59) and South Nias Regency (6.77). The whole region is considered to have a very large dependence on central government assistance.

Based on administrative regions, the majority of regions with the smallest share are located in North Sumatra Province which is similar to cases that occur in East Java Province. These findings should become the main consideration for the central government and especially for North
Sumatra province itself in formulating regional development policy in the future and reflects the existence of wide regional inequality as well as the tendency of deep poverty in the region.

\section{B. Growth Analysis}

The domination of the district is seen from the results of the sharing analysis. Correspondingly with the result of growth analysis where the whole regions that have a great value of growth are the districts. The highest growth districts/ regencies are Mesuji Regency with the growth of 99.42 then Southeast Aceh Regency (64.83) followed by Padang Lawas Utara (56.14), Padang Panjang (53.92) and West Nias (50.09).

Two regions are located in North Sumatera Province, the remainder is divided between regions in NAD Province, West Sumatra Province, and Lampung Regency. The high value of growth in Mesuji Regency indicates the prospect of positive economic growth in the coming period. Based on statistics, the main sectors that support growth in Mesuji Regency are plantation, agriculture and farming sectors.

It can be seen that Mesuji Regency is still in the primary product-based economy. With the potential for increased growth every year, this should be a momentum to increase the value added of the products produced. It shall not only have focused on producing the main plantation, crop and livestock products but also attempts to diversify the derivative products from those sub-sectors.

For instance, the palm oil industry should start to develop its potential in cosmetic and beauty industry or other chemical industry. Similar approach shall be taken by the farming and agriculture sector. Therefore, in the future, the land limitation constraint should not be a problem. The combination of the development of the service sector is also very possible by continuing to base on economic sectors that have been well established.

The inclusion of two districts in the province of North Sumatra into the category of regions with the highest growth, which one of it is West Nias regency, is also quite interesting to be observed. West Nias Regency was previously included in the category of regions with low levels of independence. According to data from West Nias Regency BPS, the leading sectors that can continue to be developed are agriculture-based sectors, mining, and excavation.

Given the low status of independence, the strategy of prioritizing sectors that currently exist and developed, especially the mining sector, has begun to change. The West Nias District Government should be able to find other priority sectors in order to improve the aspect of regional independence. 


\section{Quadrant Method Analysis}

Based on the analysis using quadrant method, the entire region in Sumatera can be mapped according to their individual characteristics. The mapping using quadrant method is a combination of share and growth analysis. If the analysis in the Java region describes the spread of the region to all quadrants, then in Sumatra more are placed in quadrant II and quadrant IV. This means that the regions in Sumatra are spreading into groups that still have the potential for positive economic development in the future as well as the group of regions that are still lagging behind.

As for the regions that are classified in the quadrant IV shall also be a major reference for the policy-making regarding the acceleration of development and economic growth.

1. Quadrant I: About 20 regions are in quadrant I or about $12.2 \%$ of the total area analysed. Some of the regions included in quadrant I are: NAD Province, Medan City, Bengkalis Regency, Rokan Hilir Regency, Pekanbaru City, Meranti Islands District, Anambas Islands Regency, Sarolangun Regency, Jambi City, South Sumatera Province, Lahat Regency, Muara Enim Regency, OKU District, Prabumulih City, Bangka Belitung Province, Pangkal Pinang City, Bengkulu Province, Lampung Province, Metro City and Mesuji Regency. These regions are the ideal regions because they have great independence and positive economic growth. These regions should be the main target and priority of investment in the region facilitated by the central government;

2. Quadrant II: there are about 54 regions in quadrant II or about $32.93 \%$ of the total region. These regions have low independence but have positive economic growth prospects. From the 54 regions in this quadrant II, about 17 regions are in North Sumatra Province. While the remaining are spread in NAD Province, West Sumatera Province, Jambi Province, South Sumatera Province, Bengkulu Province and Lampung Province. If in quadrant I most of the economy is still driven by the oil and gas sector, in this second quadrant the regions in average are making the agricultural sector, plantation and excavation as a priority sector; please revise the English sentences so it can easily be understood.

3. Quadrant III: about 35 regions or $21.34 \%$ of the entire locus regions of observation. The regions included in the quadrant III deemed to be not ideal despite its high share, thus the independence of the regions is successful, but the economic prospect in the future is negative because the value of its growth is low in contrast to the area in Quadrant II. Based on the distribution of the region it is relatively balanced across the region, there are eight regions in Riau Province, seven regions in Riau Islands Province, seven regions in Jambi province, the other seven in South Sumatra Province and the rest are divided between NAD Province, North Sumatera, West Sumatra and Lampung;

4. Quadrant IV: the largest part of the regional classification in the Sumatra region is in this IV quadrant, a quadrant that is not ideal because it describes regions with low independence and a negative economic outlook. Policy-making related to regional development should target the regions in this quadrant IV as a reflection of regions that are still left behind.

\section{ConClusion}

The implementation of reformation era's decentralization started since 1 January 2001. The essential purpose of this implementation is to accelerate public welfare through improvement of public services, which is more efficient from the regional government. Owing to this, the implementation of fiscal decentralization is assigned to these three aspects, which are political decentralization, administrative decentralization, and fiscal decentralization.

Fiscal decentralization then becomes the main benchmark for the successful implementation of decentralized relationship patterns, through indicators of regional independence through enhancement of regional capabilityin exploring Local Own Revenue (PAD). Then fiscal decentralization is expected to be transformed as a key to overcoming various problems in the region.

From these indicators, regional inequalities along with poverty are the government's priority. Government plans to make the budget allocation more effective to resolve regional inequality and poverty problems through the inclusive economic growth strategy. Based on this urgency, it is very interesting to undergo the research on the Sumatera Regions as the second largest supporter for national economic growth after Java Island.

In this research, a quantitative approach is used to calculate the indicators of share and growth. Share indicator to show the aspect of regional independence to finance its APBD while growth to show the prospect of economic growth in the future. Analysis of the share and growth will be combined with the quadrant method as the basis of the grouping of regions into four quadrants based on their respective characteristics with the type of data across Sumatra of 2010-2016.

Based on the calculation results, it uncovers the Bengkalis District with an average share of the year 2010-2016 amounted to 94.28. Followed by 
Riau Province, Siak Regency, Rokan Hilir Regency and Musi Banyuasin Regency. This position is unique to be observed because of the composition is very different from the results of share analysis in Java. The majority of regions with the largest share in Java are still dominated by the province.

Meanwhile, the regions with the smallest share if the group to the top five consists of West Nias Regency, North Nias Regency, Toba Samosir Regency, Gunung Sitoli City and South Nias Regency. The whole regions are considered to have a very large dependence on central government assistance and must be the main consideration for the local government in the districts and provinces to immediately think of solutions for increasing the independence of the region through the aspect of the increase in PAD and other aspects.

For the growth analysis, the highest growth region is Mesuji Regency with the growth of 99.42 then followed by Southeast Aceh Regency, Padang Lawas Utara, Padang Panjang and West Nias. Two regions are located in North Sumatera Province, the remainder is divided between regions in NAD Province, West Sumatra Province, and Lampung Regency.

The result of quadrant method shows that 20 regions are in Quadrant I or about $12.2 \%$ of the total area analysed such are: NAD Province, Medan City, Bengkalis Regency, Rokan Hilir Regency, Pekanbaru City, Meranti Islands District, Anambas Islands Regency, Sarolangun Regency, Jambi City, South Sumatera Province, Lahat Regency, Muara Enim Regency, OKU District, Prabumulih City, Bangka Belitung Province, Pangkal Pinang City, Bengkulu Province, Lampung Province, Metro City and Mesuji Regency.

About 54 regions in Quadrant II or about $32.93 \%$ of the total region. These regions have low independence but have positive economic growth prospects. North Sumatra Province is among the other, while the remaining are spread in NAD Province, West Sumatera Province, Jambi Province, South Sumatera Province, Bengkulu Province and Lampung Province. If in quadrant I most of the economy is still driven by the oil and gas sector, in this second quadrant the regions in average are making the agricultural sector, plantation, and excavation as a priority sector.

The regions belonging to Quadrant III are about 35 regions or $21.34 \%$ of the entire locus regions of observation. The regions included in the quadrant III deemed to be not ideal despite its high share, thus the independence of the regions is successful, but the economic prospect in the future is negative because the value of its growth is low in contrast to the area in Quadrant II. Numerous oil and gas producing regions are located in this quadrant also strengthens the need for oil and gas regions to immediately conduct Sectoral Migration.

Dissimilar with the analysis in Java, the Sumatera region's economy is high dependence on the natural-resources economy. Some of the regions natural resources contribution are still in their golden period, therefore having great region independency aspect, meanwhile, the other regions have entered into the ending period of their natural resources contribution. Other dominant sectors are agriculture, plantation, and excavation.

In relation to the phenomenon of the natural resource curse, the central government should be able to provide recommendations in the regions to initiate sectoral migration initiation when natural resource revenue is still positive. Regions must use all revenue of natural resources as a capital for non-oil infrastructure development. Regions are also obliged to prioritize industries that are able to process agricultural, plantation and excavation products with added value in order to create sustainable growth.

The regional condition in Sumatera has numerous regions that are still in Quadrant IV that means low independence and the prospect of negative economic growth. A common solution should be sought in this regard, for example, reforming the central government's policy of providing $\mathrm{TkD}$ assistance to regions by promoting the real fiscal disparity aspect. The central government should be able to create a policy formulation that underpins the regions in the IV quadrant. Unproductive budgeting shall be diverted into investment expenditures and service development.

\section{ACKNOWLEDGEMENT}

In this paper, the author will express his gratitude to the Fiscal Policy Agency (BKF) and Directorate General Fiscal Balance (DJPK) which have provided data for this study. And also, many related stakeholders which have supported the implementation of research activities so that this study can be completed.

\section{REFERENCES}

A., K. I. P. (2016). Resource Abundance and Its Impact on Latin American Economic Growth. Journal of Behavioural Economics, Finance, Entrepreneurship, Accounting and Transport, 4(3), 54-70. http://doi.org/10.12691/jbe-43-3

A., R. (2013). Desentralisasi Fiskal dan Pertumbuhan Ekonomi, serta Kaitannya dengan Otonomi 
Daerah. Jurnal Borneo Administrator, 9(3), 284-304. http://doi.org/10.24258/jba. v9i3.124

Allo, R. R. B., \& Mahi, B. R. (2014). Analisis Hubungan Kemandirian Fiskal dan Efisiensi Belanja Pemerintah Daerah di Jawa Tengah. University of Indonesia.

Anwar, E., Kumenaung, A., \& Kawung, G. (2015). Analisis Kemandirian Fiskal Tahun 2010-2012 Daerah Kabupaten/Kota Provinsi Sulawesi Utara. Jurnal Berkala Ilmiah Efisiensi, 15(1), 1-12. Retrieved from https://ejournal.unsrat. ac.id/index.php/jbie/article/view/6258

Apriana, D., \& Suryanto, R. (2010). Analisis Hubungan Antara Belanja Modal, Pendapatan Asli Daerah, Kemandirian Daerah dan Pertumbuhan Ekonomi Daerah (Studi pada Kabupaten dan Kota se Jawa-Bali). Jurnal Akuntansi \& Investasi, 11(1), 68-79. Retrieved from http://journal. umy.ac.id/index.php/ai/article/view/1075

Apriesa, L. F., \& Miyasto. (2013). Pengaruh Desentralisasi Fiskal terhadap Pertumbuhan Ekonomi Daerah dan Ketimpangan Pendapatan (Studi Kasus: Kabupaten/Kota di Jawa Tengah). Diponegoro Journal of Economics, 2(1), 1-12. Retrieved from https://ejournal3.undip.ac.id/ index.php/jme/article/view/1916/1914

Basri, H., Syaparudin, \& Junaidi. (2013). Pemetaan Kinerja Pendapatan Asli Daerah dan Kemampuan Keuangan Daerah Kabupaten/ Kota di Provinsi Jambi. Jurnal Perspektif Pembiayaan Dan Pembangunan Daerah, 1(2), 81-90. Retrieved from https://online-journal. unja.ac.id/index.php/JES/article/view/1497

Borge, L.-E., Parmer, P., \& Torvik, R. (2015). Local natural resource curse? Journal of Public Economics, 131(Supplement C), 101-114. http://doi.org/10.1016/j. jpubeco.2015.09.002

Cahyono, B. D. (2014). Identifikasi Derajat Kompetisi Fiskal Kabupaten/Kota di Jawa Timur. Jurnal Ekonomi Dan Pembangunan, 22(1), 47-54. Retrieved from http://jurnalekonomi.lipi. go.id/index.php/JEP/article/view/30

Direktorat Pengembangan Otonomi DaerahBappenas. (2003). Peta Kemampuan Keuangan Provinsi dalam Era Otonomi Daerah: Tinjauan atas Kinerja PAD dan Upaya yang Dilakukan Daerah. Bappenas. Retrieved from https://www.bappenas. go.id/files/4613/5230/1470/15petakemampuan-keuangan-provinsi-dalam-eraotonomi-daerah-tinjauan-atas-kinerja-paddan-upaya-yang-dilakukan-daerah__20081123002641_14.pdf

Dwirandra, A. A. N. B. (2013). Pengaruh Desentralisasi Fiskal pada Pertumbuhan Ekonomi dengan Keserasian Belanja Daerah sebagai Variabel Pemoderasi. Jurnal Ilmiah Akuntansi Dan Bisnis, 8(2), 66-74. Retrieved from https://ojs.unud.ac.id/index.php/jiab/ article/view/10860

Efendi, D., \& Wuryanti, S. (2011). Analisis Perkembangan Kemampuan Keuangan Daerah dalam Mendukung Pelaksanaan Otoda di Kabupaten Nganjuk. In Prosiding Seminar Nasional Ilmu Ekonomi Terapan 2011 (pp. 1-10). Lembaga Penelitian dan Pengabdian Kepada Masyarakat, Universitas Muhammadiyah Semarang.

Enceng, Irianto, L. B., \&W., P. M. (2012). Desentralisasi Fiskal Penerimaan Keuangan Daerah. JIANA (Jurnal Ilmu Administrasi Negara), 12(1), 6173. Retrieved from https://ejournal.unri.ac.id/ index.php/JIANA/article/view/904

Fatoni, I., \& Nurhayati, I. D. (2013). Pengaruh Anggaran dan Pengendalian terhadap Efektivitas Kinerja Satuan Kerja Perangkat Daerah (SKPD) di Kabupaten Malang. Jurnal Manajemen Dan Akuntansi, 2(3), 17-30. Retrieved from http://publishing-widyagama. ac.id/ejournal-v2/index.php/jma/article/ view $/ 247$

Habibi, M. M. (2015). Analisis Pelaksanaan Desentralisasi dalam Otonomi Daerah Kota/ Kabupaten. Jurnal Pendidikan Pancasila Dan Kewarganegaraan, 28(2), 117-124. Retrieved from http://journal.um.ac.id/index.php/jppk/ article/view/5452

Harteti, Y., Darwanis, \& Abdullah, S. (2014). Pengaruh Desentralisasi Fiskal dan Belanja Daerah terhadap Kinerja Keuangan Daerah pada Kabupaten/Kota di Provinsi Aceh. Jurnal Magister Akuntansi: Pascasarjana Universitas Syiah Kuala, 3(3), 90-99. Retrieved from http://www.jurnal.unsyiah.ac.id/JAA/article/ view/4438

Indriyani, \& Pandansari, T. (2016). Pengaruh PDRB dan Aset terhadap Penerimaan Daerah serta Implikasinya pada Kinerja Keuangan Pemerintah Kabupaten/Kota di Jawa Tengah. Jurnal Manajemen Dan Bisnis Media Ekonomi, $X V I(1), 130-149$. Retrieved from http:// jurnalnasional.ump.ac.id/index.php/MEDEK/ article/view/1279

Irawan, S., \& Tacconi, L. (2016). Intergovernmental Fiscal Transfers, Forest Conservation and Climate Change. Edward Elgar Publishing.

Kharisma, B. (2013). Desentralisasi Fiskal dan Pertumbuhan Ekonomi: Sebelum dan Sesudah Era Desentralisasi Fiskal di Indonesia. Jurnal Ekonomi Dan Studi Pembangunan, 14(2), 101119. Retrieved from http://journal.umy.ac.id/ index.php/esp/article/view/1249

Litvack, J., Ahmad, J., \& Bird, R. (1998). Rethinking Decentralization in Developing Countries. The 
World Bank Sector Studies Series. Washington, D.C.: The World Bank. Retrieved from http://documents.worldbank.org/curated/ en /938101468764361146/Rethinkingdecentralization-in-developing-countries

Lounela, A. (2015). Climate change disputes and justice in Central Kalimantan, Indonesia. Asia Pacific Viewpoint, 56(1), 62-78. http://doi. org/10.1111/apv.12088

Magno, R. B., Hakim, A., \& Domai, T. (2015). Pengaruh Pengelolaan Anggaran Terhadap Kinerja Organisasi Pemerintahaan. Reformasi, 5(2). Retrieved from https://jurnal.unitri. ac.id/index.php/reformasi/article/view/315

Mardiasmo. (2009). Akuntansi Sektor Publik. Yogyakarta: Andi Offset.

Muin, F. (2014). Otonomi Daerah dalam Persepektif Pembagian Urusan Pemerintah-Pemerintah Daerah dan Keuangan Daerah. Fiat Justisia Jurnal Ilmu Hukum, 8(1), 69-79. http://doi. org/10.25041/fiatjustisia.v8no1.288

Nanda, R., \& Darwanis.(2016). Analisis Implementasi Anggaran Berbasis Kinerja pada Pemerintah Daerah (Studi Deskriptif pada Dinas DPKKD Kabupaten Aceh Selatan). Jurnal Ilmiah Mahasiswa Ekonomi AKuntansi (JIMEKA), 1(1), 327-340. Retrieved from http://www.jim. unsyiah.ac.id/EKA/article/view/778

Nurhemi, \& Suryani, G. (2015). Dampak Otonomi Keuangan Daerah terhadap Pertumbuhan Ekonomi di Indonesia. Buletin Ekonomi Moneter Dan Perbankan, 18(2), 183-206. Retrieved from http://bmeb-bi.org/index. php/BEMP/article/view/522

Oates, W. E. (1972). Fiscal Federalism. New York: Harcourt Brace Jovanovich.

Oates, W. E. (2011). Fiscal Federalism. Cheltenham: Edward Elgar Publishing.

Polterovich, V., Popov, V., \& Tonis, A. (2010). Resource abundance: A curse or blessing? (DESA Working Paper No. 93). DESA Working Paper No. 93. http://doi.org/10.2139/ssrn.1814382

Pujiati, A. (2008). Analisis Pertumbuhan Ekonomi di Karesidenan Semarang Era Desentralisasi Fiskal. Economic Journal of Emerging Markets, 13(2), 61-70. Retrieved from http://jurnal.uii. ac.id/JEP/article/view/221

Rampengan, M., Nangoi, G. B., \& Manossoh, H. (2016). Analisis Efektifitas dan Efisiensi Pelaksanaan Anggaran Belanja Badan Perencanaan Pembangunan Daerah (Bappeda) Kota Manado. Jurnal Berkala Ilmiah Efisiensi, 16(3), 616-623. Retrieved from https://ejournal.unsrat.ac.id/ index.php/jbie/article/view/13530

Rondinelli, D. A. (1989). Decentralizing Public Services in Developing Countries: Issues and Opportunities. The Journal of Social, Political, and Economic Studies, 14(1).
Rosser, A. (2006). The Political Economy of the Resource Curse: A Literature Survey (IDS Working Paper No. 268). IDS Working Paper 268. Retrieved from http://www.ids.ac.uk/ publication/the-political-economy-of-theresource-curse-a-literature-survey

Sagala, L. M., \& Parmadi. (2013). Analisis Kemampuan Keuangan Daerah: Studi Kasus Kota Jambi dan Kabupaten Batanghari. Jurnal Paradigma Ekonomika, 1(8). Retrieved from https://online-journal.unja.ac.id/index.php/ paradigma/article/view/1696

Samora, R. (2010). Peta Kemampuan Keuangan Daerah pada Pemerintahan Kota dan Kabupaten Se-Jawa dan Bali Tahun 2004-2008: Metode Kuadran. Jurnal Akuntansi Kontemporer, 2(1), 65-84. Retrieved from http://journal.wima. ac.id/index.php/JAKO/article/view/437

Saputra, D. (2014). Analisis Kemandirian dan Efektivitas Keuangan Daerah pada Kabupaten dan Kota di Propinsi Sumatera Barat. Jurnal Akuntansi, 2(1), 1-26. Retrieved from http:// ejournal.unp.ac.id/students/index.php/akt/ article/view/871

Sasana, H. (2009). Analisis Dampak Pertumbuhan Ekonomi, Kesenjangan Antar Daerah dan Tenaga Kerja Terserap terhadap Kesejahteraan di Kabupaten/Kota Provinsi Jawa Tengah dalam Era Desentralisasi Fiskal. Jurnal Bisnis Dan Ekonomi (JBE), 16(1), 50-69. Retrieved from http://www.unisbank.ac.id/ojs/index. php/fe3/article/view/315

Sasana, H. (2011). Analisis Determinan Belanja Daerah di Kabupaten/Kota Provinsi Jawa Barat dalam Era Otonomi dan Desentralisasi Fiskal. Jurnal Bisnis Dan Ekonomi (JBE), 18(1), 46-58. Retrieved from https://www.unisbank.ac.id/ ojs/index.php/fe3/article/view/529

Sasana, H. (2015). Dampak Implementasi Desentralisasi Fiskal terhadap Pertumbuhan Ekonomi dan Stabilitas Harga di Provinsi di Indonesia. Media Ekonomi Dan Manajemen, 30(1), 1-14. http://doi.org/10.24856/mem. v30i1.230

Sianturi, A., Sjamsuddin, S., \& Domai, T. (2014). Peran Pendapatan Asli Daerah dalam Menunjang Desentralisasi Fiskal dan Pembangunan Daerah (Studi pada Dinas Pendapatan Kota Batu). Jurnal Administrasi Publik (JAP), 2(3), 557-563. Retrieved from administrasipublik. studentjournal.ub.ac.id/index.php/jap/ article/view/424

Suharizal. (2012). Demokrasi Pemilukada dalam Sistem Ketatanegaraan RI. Bandung: UNPAD Press.

Sulistio, E. B. (2010). Proses Penyusunan Anggaran Berbasis Kinerja (Studi pada Pemerintah Kabupaten Way Kanan). Administratio (Jurnal 
Ilmiah Administrasi Publik Dan Pembangunan), 1(1), 39-49.

Sumarsono, H. (2009). Analisis Kemandirian Otonomi Daerah: Kasus Kota Malang (19992004). JESP, 1(1), 13-26. Retrieved from http://journal.um.ac.id/index.php/jesp/ article/view/5121

Supriyadi, Armandelis, \& Rahmadi, S. (2013). Analisis Desentralisasi Fiskal di Kabupaten Bungo. Jurnal Perspektif Pembiayaan Dan Pembangunan Daerah, 1(1), 1-10. Retrieved from https://online-journal.unja.ac.id/index. php/JES/article/view/1336

Susilo, G. T. B., \& Adi, P. H. (2007). Analisis Kinerja Keuangan Daerah Sebelum dan Sesudah Otonomi Daerah (Studi Empiris di Provinsi Jawa Tengah). In Konferensi Penelitian Akuntansi dan Keuangan Sektor Publik Pertama. Surabaya.

Tama, A. I. (2015). Analisis Kinerja Keuangan Pemerintah Daerah Melalui Analisis Rasio Keuangan APBD Kabupaten/Kota di Indonesia Sebelum dan Sesudah Penerapan UndangUndang Nomor 28 Tahun 2009. JRAK, 6(2), 20-32. Retrieved from http://www.ejournalunisma.net/ojs/index.php/jrak/article/ view/1454

Taqwa, D. F., Priyono, T. H., \& Santosa, S. H. (2016). Pengaruh Desentralisasi Fiskal Terhadap Pertumbuhan dan Kesenjangan Daerah di Provinsi Jawa Timur Tahun 2010-2014. Artikel Ilmiah Mahasiswa. Retrieved from http://repository.unej.ac.id/bitstream/ handle/123456789/75109/DEVIS FAUQIATU TAQWA.pdf?sequence $=1$
Tiebout, C. M. (1956). A Pure Theory of Local Expenditures. Journal of Political Economy, 64(5), 416-424. http://doi. org/10.1086/257839

Tiyaningsih, A. A. (2009). Analisis Derajat Desentralisasi Fiskal Kota Malang Tahun 20014-2008. Jurnal Ekonomi Pembangunan, 7(2), 85-100. Retrieved from http://ejournal. umm.ac.id/index.php/jep/article/view/3586

UNDP (United Nations Development Programme). (2009, May). The Missing Link: The Province and Its Role in Indonesia's Decentralisation. Policy Issues Paper. Jakarta, Indonesia: UNDP (United Nations Development Programme).

Wenny, C. D. (2012). Analisis Pengaruh Pendapatan Asli Daerah (PAD) terhadap Kinerja Keuangan pada Pemerintah Kabupaten dan Kota di Propinsi Sumatera Selatan. Forum Bisnis Dan Kewirausahaan Jurnal Ilmiah STIE MDP, 2(1), 39-51. Retrieved from http://eprints.mdp. ac.id/676/

Widyantoro, A. E. (2009). Implementasi Performance Based Budgeting: Sebuah Kajian Fenomenologis (Studi Kasus pada Universitas Diponegoro). Diponegoro University. Retrieved from http:// eprints.undip.ac.id/24007/

Yuana, A. P. (2014). Analisis Kinerja Keuangan Daerah terhadap Pertumbuhan Ekonomi dan Ketimpangan Regional di Era Desentralisasi Fiskal (Studi Kabupaten/Kota di Provinsi Jawa Timur Periode 2008-2012). Jurnal Ilmiah Mahasiswa FEB Universitas Brawijaya, 2(2). Retrieved from http://jimfeb.ub.ac.id/index. php/jimfeb/article/view/1107 